\title{
Proximal myotonic myopathy
}

INSERM

\section{Source}

INSERM. (1999). Orphanet: an online rare disease and orphan drug data base. Proximal myotonic myopathy. ORPHA:606

Myotonic dystrophy type 2 (MD2), also known as proximal myotonic myopathy, is a very rare genetic multi-system disorder of late childhood or adult-onset characterized by mild myotonia, muscle weakness, and rarely cardiac conduction disorders. 